\title{
Occupational Mobility Chains and the Role of Job Opportunities for Upward, Lateral and Downward Mobility in Switzerland
}

\begin{abstract}
This paper addresses the rarely studied relationship between job vacancies and interfirm upward, lateral, and downward status mobility in an occupationally segmented labor market, taking Switzerland as the example. To conceptualize mobility mechanisms in this type of labor market, we introduce the concept of "occupational mobility chains" and test its validity. This concept provides the backdrop for developing time-dependent measures of individual job opportunities based on Swiss Job Monitor data. We link these measures with career data taken from the Swiss Life History Study and employ event history analysis to test different propositions of the ways in which status mobility is contingent on the number and the status of vacant positions. Results support our assumption that in occupationally segmented labor markets vacant positions affect status mobility only to the degree that they are located within workers' occupational mobility chains.
\end{abstract}

Keywords: occupational status mobility, vacancies, labor-market segmentation, job opportunities, occupational mobility chains 


\section{Introduction}

This paper examines how job vacancies affect inter-firm status mobility in the occupationally segmented Swiss labor market, where status mobility is predicated on a change of occupation. Our analysis of the rarely studied relationship between vacancies and between-firm status mobility distinguishes between upward, lateral, and downward mobility, testing whether and how these three mobility types are contingent upon vacant positions.

To address the role of vacancies for career mobility processes, sociological research mostly draws on vacancy chain models, emphasizing the role of vacant positions within institutionalized job sequences or job ladders. From this perspective, career mobility is contingent on vacant positions as well as the number and characteristics of competitors (Chase, 1991; Rosenfeld, 1992; Stewman \& Konda, 1983). These models and the respective empirical research mainly focus on mobility within firm-internal labor markets (ILMs). ${ }^{1}$ They are of limited use, however, when between-firm status mobility processes in occupationally segmented labor markets (henceforth referred to as OLMs) are of interest. For this type of mobility and labor market we propose the new concept of "occupational mobility chains" (henceforth referred to as OMCs). Showing affinities to Spilerman's (1977: 559ff.) broad concept of "career lines," OMCs specify the conditions under which status mobility may occur despite the strong occupational segmentation of the labor market.

We are aware of three studies, conducted by Allmendinger (1989), Blossfeld (1987) and Wolbers (2008) who have examined the effects of vacancies on occupational status mobility. All of them use highly aggregate macro-level proxies, such as GNP or the unemployment rate. Allmendinger finds a positive effect of labor demand on upward mobility for Norway, the US and Germany; Blossfeld reports positive effects for Germany on upward,

1 For an exception see Harrison (1988) who analyzed aggregate mobility flows between occupational groups in external labor markets. 
lateral, and - rather surprisingly - also on downward mobility. Wolbers finds weak negative effects of the unemployment rate on upward and positive effects on downward mobility.

Research on how individual and family characteristics, such as race, sex, human capital, child birth, personality (Dekker, de Grip, \& Heijke, 2002; Gelissen \& de Graaf , 2006; Kalmijn \& Luijkx, 2006; McBrier \& Wilson, 2004; Wilson, 2009; Wilson \& Roscigno, 2010; Sicherman \& Galor, 1990) or displacement (Lippmann \& Rosenthal, 2008) affect occupational status mobility is more extensive, however. Other studies document differences in upward mobility mechanisms between types of labor markets (Sørensen \& Tuma, 1981) as well as within and between organizations (DiPrete \& Krecker, 1991). Noteworthy enough, most of these studies do not systematically compare upward, lateral, and downward status mobility; exceptions being Blossfeld (1987) and Gelissen \& de Graaf (2006).

For mobility outcomes other than occupational status mobility, research has addressed the significance of vacancies. This body of research also relies on highly aggregate and indirectly measured indicators of labor demand, such as occupational change (DiPrete, de Graaf, Luijkx, Tåhlin, \& Blossfeld, 1997; DiPrete \& Nonnemaker, 1997; Kye, 2008), unemployment, worker supply or GDP (Gesthuizen \& Wolbers 2010; Yu, 2010), and industrial ecology (e.g., firm size, firm closure, merger, and industrial growth) (Haveman \& Cohen, 1994; Fujiwara-Greve \& Greve, 2000; Stovel \& Savage 2006; Shin, 2007). The results, mostly for the US, generally show that demand forces substantially affect job mobility within and between firms, occupations, and industry.

Overall, previous research on different types of mobility demonstrates that demandside factors do matter. However, empirical evidence of demand-side effects on status mobility taking into account labor market segmentation is still missing. This paper attempts to partially fill this gap by proposing the new concept of occupational mobility chains (OMCs) to investigate status mobility processes in occupationally segmented labor markets. To our knowledge, this is the first attempt to conceptualize status mobility mechanisms in OLMs. By 
introducing time-dependent measures of vacant positions at the level of labor market segments we will be able to test empirically the implications of this concept for status mobility. Switzerland is the empirical reference as it is a prototypical case of an OLM.

\section{Theoretical considerations}

We start from the basic theoretical assumption that opportunities for status mobility strongly depend on the characteristics of the labor market in which mobility processes take place (e.g., Miller, 1982; Rosenfeld, 1992). For OLMs, we argue that skill-specific labor demand is more important for status mobility than aggregate labor demand (see also Halaby, 1988, p.11). Furthermore, the direction of individual status mobility (i.e., upward, lateral or downward) is likely to be contingent on the status of the vacant positions. In order to elaborate these basic assumptions, we will first conceptualize the Swiss OLM. Next, we explicate the concept of OMCs and discuss the role of vacancies for status mobility in this type of labor market. We conclude this section with an outline of the significance of job context and human capital for mobility processes.

\subsection{The Swiss OLM}

The Swiss labor market (like the German one) shows a profound segmentation by occupation-specific formal credentials. This type of labor market is perhaps best described by Sengenberger's (1987) concept of the tripartite labor market, distinguishing three main segments, namely the occupation-specific, the peripheral, and the firm-internal labor market. The occupation-specific segment, by far the largest in Switzerland, is subdivided in itself into some hundred occupation-specific subsegments, each of which is based on an occupationspecific formal credential. Access to jobs in these subsegments is generally limited to people holding the specific occupational credential (Blossfeld \& Mayer, 1988; Buchmann \& Sacchi, 1995; Buchmann, Sacchi \& Kriesi, 2002; Kriesi, Buchmann \& Sacchi, 2010). Consequently, 
there is limited mobility between most occupational subsegments. Mobility usually presupposes the time-consuming and costly acquisition of an additional occupation-specific credential. Between-firm mobility within occupational subsegments, however, is largely unrestricted as credentials are institutionalized and skills can thus easily be transferred between employers. The peripheral segment includes unskilled jobs for workers without postobligatory educational credentials, imposing no restrictions for mobility within this segment. In the internal labor-market (ILM), characteristic of large firms, skilled workers are recruited for entry port positions at the lower levels of the organizational hierarchy based on their occupational certificate. From there, they may climb up institutionalized career ladders. As small and medium sized firms strongly prevail in Switzerland (Buchmann, Kriesi, \& Sacchi, 2009; Levy, Joye, Guye, \& Kaufmann, 1997a), the scope of ILMs is rather limited in the Swiss labor market and their role in accounting for individual mobility processes, being overrated in general (Blossfeld \& Mayer, 1988; Kerckhoff, 1995), should thus be particularly modest.

Despite institutional restrictions to mobility between most occupational subsegments in OLMs, research shows that occupational mobility and, consequently, status mobility (as status is tied to occupation) does occur in the Swiss OLM, encompassing upward, lateral or downward mobility (Sheldon, 2005; Federal Statistical Office, 2000). Occupational mobility is relatively frequent between akin occupations (i.e., those characterized by relatively similar task and skill profiles) and rare otherwise (Buchmann \& Sacchi, 1995; Leibundgut, 1986; Sheldon, 2005).

\subsection{OMCs}

To conceptualize the clusters of relatively permeable subsegments composed of occupations with akin skill and task profiles, we introduce the notion of OMCs. It refers to Spilerman's (1977:551) broad concept of career lines and refines it for OLMs. Spilerman 
conceives of career lines as sequences of jobs. Workers holding a job within such a sequence have greater chances of moving to the next position in the sequence than other workers. Career lines thus provide mobility pathways "common to a portion of individuals in the labor force" (Spilerman, 1977:560). In contrast to vacancy chain concepts, career lines are applicable to mobility between firms, industries, and occupations (see also Kerckhoff, 1995). Whether mobility does indeed occur, depends on the vacancy structure within a worker's career line.

OMCs represent "career lines," linking a number of mutually permeable subsegments in the occupation-specific segment of the labor market and thus providing opportunities for occupational mobility. Figure 1 illustrates our concept of OMCs. The occupationally segmented labor market is represented with two dimensions: occupational status and occupational specialization. While the former refers to the vertical dimension of stratification, the latter relates to the horizontal dimension of the division of labor. OMCs are represented by links (i.e., lines) between small clusters of occupational subsegments (i.e., boxes). Vertical links indicate pathways for upward/downward mobility; horizontal links those for lateral mobility. OMCs thus provide opportunities for mobility between occupational subsegments that are not rigidly sealed off from each other. If two occupational subsegments within a mobility chain offer the same status, opportunities for lateral mobility occur. Avenues for upward or downward mobility arise when subsegments with different status belong to the same mobility chain. In essence, the concept of OMC, conceived for the external labor market, is complementary to the concept of job ladders in ILMs.

[Figure 1 about here]

To understand how OMCs work, we distinguish three mobility mechanisms. The first one is contingent upon occupation-specific tertiary-level training that is accessible only for workers equipped with the appropriate secondary-level occupational certificate. The completion of such higher-level training provides access to jobs in related (and, in Figure 1, 
adjacent) occupational subsegments characterized by higher status. Examples for the Swiss labor market are electricians receiving training to become electrical engineers, bricklayers undergoing the tertiary-level training for construction engineers or office clerks training as human resource assistants. The second mechanism posits that, for some OMCs, extended job experience serves as an equivalent to further education, especially where institutionalized opportunities for occupation-specific tertiary-level training are lacking. In these cases, workers bringing along the required occupation-specific certificate coupled with extended work experience in the respective occupation may access the subsegments of higher status within an OMC. It is only experienced bricklayers and commercial clerks, for example, who may become foremen or commercial executives, respectively. The third mechanism takes into account that recruiters, depending on the job profile of the vacancy to be filled, may regard some relatively similar occupational credentials as more or less equivalent (Kaiser, 1983). This will be especially the case in times of labor shortage, when ideally skilled workers for given vacancies are scarce (Buchmann, Sacchi, \& Kriesi, 2002). Consequently, the involved occupational subsegments become more mutually permeable and status mobility, mainly of the lateral type, is stimulated accordingly. Examples are trained insurance clerks entering the segment for finance clerks and vice versa, advertising specialists gaining access to the segment of public relation experts or trained lock smiths entering metal worker jobs and vice versa.

\subsection{Job opportunities and OMCs}

Our theoretical elaboration of OMCs, the small clusters of relatively permeable subsegments chained by the three mobility mechanisms, implies that only vacancies within a worker's OMC constitute job opportunities. The so-defined job opportunities determine a worker's status mobility chances. Vacancies outside the OMC do not represent job 
opportunities as job applicants in OLMs, due to the strong occupational segmentation, need to bring along the appropriate occupational credential. Beyond the specific credential, job opportunities are contingent upon the prevalence of the three mobility mechanisms and the overall economic situation. ${ }^{2}$ And finally, status mobility chances are also defined by recruiters' preferences for ascribed characteristics, such as age and sex. Put differently, given vacancies represent opportunities for occupational status mobility only insofar as they are located within a worker's OMC and he or she meets the additional job requirements.

While the likelihood of occupational status mobility in an OLM increases with the number of job opportunities as defined above, the likelihood of a particular direction of occupational status mobility is dependent upon the status of job vacancies pertaining to a worker's OMC. We distinguish between job opportunities in subsegments offering higher status compared to a worker's current occupation; those offering equal status and those offering lower status. Against this background, we advance the following three main hypotheses regarding the likelihood of upward, lateral, and downward status mobility in OLMs:

1. Upward status mobility between firms is more likely the more plentiful higher-status job vacancies within a worker's OMC are compared to his or her current job.

Many higher-status vacancies indicate employers' struggle with labor shortage in the upper echelons of the OMCs, thus increasing the likelihood of finding a job with higher status than the previous one. Workers with the appropriate occupation-specific credential having undergone further training at the tertiary level or those having accumulated a lot of work experience in their occupational field should particularly profit from these circumstances. By

2 Job opportunities are generally much more favorable during economic upswings than when the economy slumps. However, economic fluctuations do not ripple uniformly across labor market (sub-) segments as empirical results have shown (e.g., Döpke, 1995; Sacchi, Salvisberg, \& Buchmann, 2005).

Labor-force participants' long-term job opportunities also depend on whether their occupation-specific credentials belong to declining or growing occupational fields. Technological development, shifting competition, and demographic change alter the occupational and sector structures (OECD, 1994), thus improving job opportunities in some segments while deteriorating them in others. In the short run, economic up- and downswings affect individual job opportunities to a greater extent than the slower proceeding structural change. 
contrast, the number of job opportunities in the current (last) occupation as well as those offering equal or lower status are not expected to affect upward mobility processes.

2. Lateral status mobility is most likely to occur when job opportunities in those subsegments of the OMC offering equal status are particularly favorable compared to one's current occupation.

Lateral status mobility may be either voluntary or the result of individual adaptation processes tied to declining job opportunities in the occupation in which individuals work. Such moves mostly happen into occupations with skill and task profiles that are akin to the current occupation (Leibundgut, 1986). Employers regard similar occupational credentials as substitutes, implying that the change of occupation thus does not require costly retraining.

3. Downward status mobility is likely to occur when vacant positions within a given OMC concentrate in occupational subsegments characterized by lower status than the current one.

Downward status mobility is mostly involuntary, taking place when workers are forced to accept a job of lower status than the one they previously held. This may be due to (impending) unemployment or unacceptable working conditions in the job of origin. Downward status mobility is most likely when, at the same time, the number of job opportunities offering at least equal or higher status is low. Vice versa, the risk of downward mobility should be low when the number of job opportunities offering equal or higher status is high.

\subsection{Prerequisites for the conceptual validity of OMCs}

Positive tests of the above hypotheses do not yet yield ultimate confirmation of the validity of the concept of OMCs for occupationally segmented labor markets. This concept 
maintains that only job vacancies within OMCs constitute job opportunities and thus affect status mobility chances. If the occupational segmentation of the labor market plays a minor role only, vacancies independent of their allocation in the segmented labor market should be relevant for status mobility chances. For this case, our first alternative hypothesis claims that the number of vacancies of higher, equal, or lower status, respectively, across the entire labor market determines upward, lateral and downward mobility chances. Confirmation of our concept of OMCs would also be refuted if simply the business cycle influences status mobility chances. The second alternative hypothesis thus states status mobility is entirely determined by the total number of vacancies. The third and final alternative hypothesis assumes that labor demand (i.e., vacancies) is more or less irrelevant for status mobility processes. In order to assess the explanatory power of our theoretical concept of OMCs, we will test these three alternative hypotheses and compare the findings with those resulting from our three main hypotheses.

\subsection{Job context, human capital and mobility processes}

Besides job opportunities, structural characteristics of the job and workers' human capital affect status mobility. Regarding the structural characteristics of sector we expect the private sector to trigger mobility irrespective of direction as competition dominates this sector of the economy (Hachen, 1988, 1992). The public sector, by contrast, functions as a kind of internal labor market (Becker, 1993), thus reducing the likelihood of experiencing across-firm mobility moves. We expect big firms, usually characterized by internal labor markets, to show similar effects for similar reasons. Moreover, we expect self-employed people to be generally more immobile as they usually have established their company with a long-term perspective and considerable time investment. Jobs with formal authority may result in greater immobility as workers in these jobs have often accumulated much firm-specific experience and know- 
how rendering mobility costly for both employers and employees. Finally, occupational group acknowledges that occupational subsegments differ regarding the extent of job destruction leading to displacement. Compared to employed workers looking for a new job, displaced workers are more often forced to accept downward mobility in order to avoid unemployment (Lippmann \& Rosenthal 2008; Malo \& Muñoz-Bullón 2008). In subsegments with a high number of displaced workers unfavorable mobility outcomes should thus irrespective of the number and status of the job opportunities - be more frequent.

The likelihood to experience between-firm occupational status mobility also depends on workers' education, work experience, and career continuity. From the employers' perspective, these three attributes may signal productivity and other kinds of job-relevant behavior (e.g., work commitment), thus providing competitive advantages for being hired into higher-status jobs, particularly during the earlier career stages. We expect upward mobility chances, but also lateral moves, to increase with higher education, more work experience, and for workers with uninterrupted careers. Similarly, risks of downward mobility is expected to diminish with increasing levels of education and work experience and to be lower for those with uninterrupted careers as employers generally prefer workers with these attributes and place them at the front of the labor queue.

\section{Data and methods}

\subsection{Data}

The analyses are based on two data sets. Life course information is taken from the Swiss Life History Survey (Buchmann \& Sacchi, 1997). The data was collected retrospectively in 1989 from a random sample of Swiss citizens of both sexes, born between 1949-51 and 195961, respectively, in the German-speaking part of Switzerland (comprising 65 percent of the Swiss population). The survey includes detailed information on education, the family, and the 
employment history $(n=2300){ }^{3}$ Employment includes jobs of a minimum duration of four months held after the completion of formal education and covers inter-firm mobility. ${ }^{4}$

The data of the Swiss Life History Survey is comparatively old. However, it is unlikely that this diminishes the topicality and validity of the findings. The reason is that the vocational specificity of the educational system and its tight link with the labour market has remained stable over the last decades (Sheldon, 2005). Recent empirical results show that the training occupation remains the most important predictor of the occupation held in the labour market, and a change of occupation in the early career leads to lower pay (Müller \& Schweri, 2015; Buchs, Müller \& Buchmann, 2015).

The measurement of individual job opportunities is based on the Swiss Job Monitor, a representative random sample of job ads published in newspapers and advertisers in the German-speaking part of Switzerland since 1950 (Sacchi, Salvisberg, \& Buchmann, 2005). The sample was drawn by a two-stage method, whereby approximately 70 newspapers and advertisers (stratified by region and circulation) were selected. For each year, we then randomly selected between 600-700 job ads published in the selected newspapers and advertisers. For the observation period the database includes 20000 job ads with a total of 27,000 vacant positions. ${ }^{5}$ The data provide annual, occupation-specific information on advertised jobs. $^{6}$

Job ads are valuable indicator of job requirements and employers' staffing needs (Dörfler \& van de Werfhorst, 2009; Jackson, Goldthorpe, \& Mills, 2005; Schulz, Maas, \& Leeuwen,

3 Selection bias due to mortality before data collection and recall errors may hamper retrospectively collected data. The issue of mortality should be negligible for the Swiss Life History Survey given its focus on Swiss citizens below the age of 40 . As for recall errors, research has shown that retrospectively collected data on individuals' family, education, and employment history is fairly accurate (e.g., Solga, 2001).

4 This data is thus suitable for an empirical analysis of OMCs in external labor markets. Inter-firm mobility is much more prevalent than intra-firm mobility in many labor markets, including the Swiss one (DiPrete \& Krecker, 1991; Le Grand \& Tahlin, 2002; Uunk, Mach, \& Mayer, 2005; Zühlke \& Goedicke, 2000).

5 The number of advertised jobs was weighted in order to compensate for small selection probability differences. For the observation period (1960 to 1989) the focus on job ads published in print media is legitimate as electronic job ads were not yet relevant.

6 The data does not allow a reliable distinction between local labor markets within the German-speaking part of Switzerland. We do not consider this as a problem, however. Given the size of this part of the country, commutes between regions and cities are feasible. Differences in unemployment rates between regions of the German-speaking part of Switzerland are also small (BFS, 2008). 
2014). They represent sensitive indicators of excess skill demand within a labor market, thus serving as appropriate measures of employment opportunities for individuals with specific characteristics (Kriesi, Buchmann, \& Sacchi, 2010). Theoretical considerations (Sacchi, Salvisberg, \& Buchmann, 2005) and empirical evidence (Cramer, 1990; Reyher, Spitznagel, \& Kretschmer, 1990) suggest that, for the observed time span (1960 to 1989), Swiss firms used this comparatively expensive and time-consuming personnel recruitment strategy conservatively, advertising mainly jobs that were hard to fill otherwise and attempting to address only individuals who would meet the critical requirements of the vacant job. The likelihood of a job to be advertised rises the more the particular skill demand exceeds the supply. This assumption is supported by the fact that the aggregated number of job vacancies advertised annually correlates extremely strongly with indicators of the Swiss Federal Statistical Office (SFSO) measuring the excess demand for labor based on regular firm surveys (Pearson's r=.97). ${ }^{7}$ Furthermore, Sacchi (2014) has shown that -- over the entireobservation span -- the annual variation in the number of advertised jobs can be fully explained by the ups and downs in these official indicators of labour demand. The reliability of job ads as a measure of skill demand is further supported by the finding that a comparatively high and temporally stable proportion of vacant jobs in the Swiss labor market, covering all types of companies, occupations, and positions including unskilled jobs, are advertised in print media (Sacchi, Salvisberg, \& Buchmann, 2005). Swiss job ads also differentiate between the demand for male, female, older and younger workers, indicating employers' sex and age preferences regarding the future job incumbents (dito). All in all, the aggregate number of job ads is thus a sound indicator for the labor demand workers with

7 This correlation refers to the indicator series measuring the excess demand for skilled work in the period from 1983-2003. For unskilled work, the respective correlation is smaller (.86) as this type of excess demand was no longer substantial during the time period in question. 
particular combinations of occupational qualifications, work experience, and work-related personality attributes. ${ }^{8}$

\subsection{Measures}

Our dependent variable is occupational status mobility. Status mobility is contingent on a change of occupation, defined as a change in the detailed five-digit code of the 1990 occupational classification of the SFSO (375 categories). We take into account only first change of occupation that occurs when individuals change employers (i.e., firms). Occupational status mobility is measured with Treiman's occupational prestige score (Treiman, 1977). ${ }^{9}$ The choice of a relative definition of occupational status mobility ensures comparability between respondents' status mobility regardless of their base level of occupational status (see Blossfeld, 1987 for a similar approach). Respondent's upward mobility is defined as the first inter-firm change of occupation resulting in more than a 10 percent increase in the Treiman status score. Correspondingly, downward mobility is more than a 10 percent decrease in occupational status. Lateral mobility ranges within $+/-10$ percent of the former occupational status. ${ }^{10}$

Turning to the covariates, we constructed four measures of individual job opportunities, each capturing the annual number of a particular type of advertised vacancies within a worker's OMC. The first indicator measures the vacancies in a worker's current (or

\footnotetext{
A word of caution is appropriate nevertheless. Job ads may not discriminate that well between few and no job opportunities at the lowest end of the scale. Employers may already stop advertising jobs when labor demand is fairly low but has not yet reached the bottom.

9 We acknowledge that Treiman scores are perhaps no longer the best choice for measuring occupational status. For the time period under investigation (1960 to 1989), there is no better alternative available for Switzerland, however (for a review see Bergmann \& Joye, 2001). Moreover and astonishingly enough, different scales with varying theoretical underpinnings mostly yield highly similar results in empirical applications (ibd.: 28f).

10 Our model for upward mobility takes into account possible ceiling effects by excluding episodes where the respondent held a job with a status score higher than 70 (see also Blossfeld, Golsch, \& Rohwer, 2007). In these jobs, respondents cannot make a status gain of more than 10\%. In the model for downward mobility, no exclusions were necessary to account for possible bottom effects.
} 
last) occupation; ${ }^{11}$ the second one those with more than 10 percent higher status on the Treiman scale compared to the current occupation; the third one those with status scores ranging within 10 percent of the current occupation; and the fourth one those with more than 10 percent lower status compared to the current occupation.

The construction of these four indicators (described in detail in Appendix A) is based on three major steps. To determine a given worker's OMC, we first estimate the probability with which a worker with an occupational credential $\mathrm{x}$ is able to access jobs in other occupations. ${ }^{12}$ This estimate is based on detailed Census Data, yielding a weight variable (“accessibility weight”). In the second step, we apply the credential-specific accessibility weights to the occupation-specific annual numbers of advertised jobs. For each credential, the number of accessibility-weighted jobs is then summed up across all occupations for each year in the observation period. The weighting guarantees that the so-defined indicator considers vacancies only to the extent that they represent job opportunities, namely, vacancies within a worker's OMC. The opportunity indicators also take into account additional job requirements by separately summing up the accessibility-weighted number of jobs with varying requests regarding work experience, age, and sex (Details in Appendix A). The third and final step links the opportunity-indicators with the dataset on individual career sequences, thus assigning the customized indicator of job opportunities to each point of the individual career.

To test the explanatory power of the concept of OMCs, we need to construct five additional job opportunity indicators. The first alternative hypothesis requires four additional indicators, constructed in the same way as the four principal job opportunity indicators described above except for disregarding the accessibility weights. They measure the overall number of vacancies in the current occupation and in occupations with higher, lower, and

11 For employment spells, the indicator refers to the occupation held. For spells of non-employment, it refers to the occupation of the last job held. As the overwhelming majority of the observed spells (80.7\%) cover spells of employment (see Table 1) we will use the term ,vacancies in the current occupation "for simplicity's sake.

12 It would be preferable to measure OMCs more directly. This would presuppose detailed micro data on jobspecific credential requirements for detailed occupational categories. To our knowledge such data is not available. 
similar status across all occupational subsegments, thus neither taking into account the strong occupational segmentation of the Swiss labor market or the enhanced permeability between the subsegments belonging to the same OMC. ${ }^{13}$ The business cycle, referring to the second alternative hypothesis, is measured by the aggregated number of vacant jobs per year, thus capturing the overall labor demand in the Swiss labor market.

Variables for job context include firm type distinguishing between jobs in the public (0) and those in the private sector (1). Firm size indicates large firms with more than 100 employees versus smaller ones. Self-employment differentiates between employees and selfemployed respondents. A dummy distinguishes jobs vested with formal authority from those that are not. Another dummy indicates whether information on some job characteristics is missing. ${ }^{14}$ For occupational groups (based on the SFSO 1990 two-digit code), administrative and office clerks serve as reference group. Occupational groups not showing a statistically significant effect have been pooled in the category "other occupations".

As for human capital, educational attainment at the time of labor-force entry distinguishes between respondents with only compulsory education, with vocational training (reference category), and with higher education combining baccalaureate, tertiary vocational training, and university. A dummy captures spells of further training after labor-force entry, assuming the value of 1 in the months of training. Labor-market experience measures months worked since labor-force entry. ${ }^{15}$ Labor force interruption is a dummy capturing months spent

13 These indicators take into account, however, whether a job is accessible for men, women, older or younger workers with or without experience.

14 The data sets provide information on several time-varying covariates for the first five jobs only (firm type, firm size, self-employment, and formal authority). The great majority of respondents held less than five jobs, however. In order not to exclude respondents who held more than five jobs during the observation period from the analysis, we substituted the missing values by assigning the mode. By including a dummy indicating the substitution of values, we are able to assess whether this procedure results in any bias.

15 In the final model we only include the linear term of labor market experience as there is not a pronounced curvilinear effect of work experience on status mobility. This is not surprising as the analyses are based on a cohort sample. This reduces the age range substantially and, hence, limits the power of the statistical test. 
without gainful employment or further training. ${ }^{16}$ Sex $(0=$ men, $1=$ women $)$ and birth cohort $(0=1949-51,1=1959-61)$ serve as control variables. Finally, the models include the abovementioned interaction terms (education, sex and duration) to handle the violations of the proportionality assumptions in the Cox model (see Appendix B for descriptives).

\subsection{Analytical strategy}

Being interested in the magnitude and the direction of covariate effects, we run Cox regression models and apply the appropriate survey weights. ${ }^{17}$ We estimate a competing risk model with three risks: upward, lateral and downward mobility. The examination of the survival rates of the time-constant covariates (gender, education, and cohort) revealed that the proportionality assumption (see Blossfeld, Hamerle, \& Mayer, 1986:83; Yamaguchi, 1991:107) is violated for education and gender. Based on Blossfeld and Rohwer (2002:243) we thus specify non-proportional Cox regression models with a parametric specification of the interaction terms between the respective covariates and duration. ${ }^{18}$ Time-varying covariates are included by episode splitting (Brüderl \& Ludwig-Mayerhofer, 1994).

The observation window begins with labor market entry of the first respondent in the early 1960 s and ends at the time of the survey in $1989 .{ }^{19}$ For mobile respondents, the observation period is defined as the time period between the month of labor-force entry after completion of formal education and the event (i.e., month of first change of occupation as defined above). For non-mobile respondents (i.e., no change in occupational code), the

16 We do not include an indicator for spells of unemployment because of their very low occurrence during the observed time period. This is due do very low unemployment figures among Swiss nationals, ranging from well below $1 \%$ in the sixties and seventies to a peak of $1.1 \%$ in the mid-eighties.

17 The weighting variable compensates for slightly differing selection probabilities and a moderate nonresponse bias (see Buchmann \& Sacchi, 1997: 121ff. for details).

18 We examined the survival rates graphically and by means of statistical tests based on Schoenfeld residuals. In the model for lateral mobility, the educational category of "higher education" and "gender" violate the assumption of parallel hazard rates. In the model for upward mobility, the educational category of "higher education" does so. In the model for downward mobility, the educational category of "compulsory schooling" and "gender" violate the assumption.

19 Although the members of the younger birth cohort were only about 30 years old at the time of the survey, a considerable proportion had already experienced occupational mobility (see Table 1). The only group that may have had insufficient time to experience mobility were university graduates- This group is small, however, amounting to only $9,8 \%$ of the cohort members (figure based on Census Data). 
observation period refers to the time period between the month of labor-force entry after completion of formal education and the month of the survey. ${ }^{20}$

The analytical strategy for testing the validity of the theoretical concept of OMCs is a stepwise model comparison based on the goodness of fit measure BIC. Following Raftery (1995:138f.), we consider a BIC difference of at least 10 as "very strong evidence" that the model with the lower BIC shows a superior fit. We compare the main model based on the four principal individual-level indicators of vacancies within a worker's OMC (henceforth referred to as model 5) with model 1 , the baseline model without covariates; model 2, based on all covariates except the job opportunity indicators; model 3, including the aggregated number of vacant jobs per year; model 4, replacing this aggregate measure by four opportunity indicators distinguishing between the current occupation and different status levels $(<10 \%$; $>10 \%$; +/$10 \%)$ without taking the accessibility of vacant jobs into account.

\section{Results}

Table 1 shows the distribution of the three types of status mobility by sex, birth cohort, and education at labor market entry. Almost 30 percent of men and women experience occupational upward mobility when they change their occupation for the first time. Women undergo considerably less lateral but more downward mobility. A similar proportion of men and women remain immobile during the observation period (35.5\% versus $37.4 \%)$. Compared to members of the birth cohort born 1959-61, the older birth cohort is slightly more mobile irrespective of the direction. As to education, people with only compulsory education experience more upward and downward status mobility than higher qualified workers. We will discuss the reasons for these differences together with the findings for the three competing risk models displayed in Table 2.

\footnotetext{
20 With unemployment in the observation period being exceedingly low in Switzerland hardly any spells of
} unemployment were observed in our data. 
[Table 1 and 2 about here]

\subsection{Effects of job opportunities}

The pattern of results for the four indicators of job opportunities, that is, vacancies within a worker's OMC (see Table 2) supports most of our theoretical assumptions, suggesting that the likelihood of upward, lateral, and downward status mobility in OLMs depends on the number and the status of job opportunities.

As expected, the number of job opportunities characterized by higher status than the current occupation $(>+10 \%)$ has a strong positive effect on upward status mobility, no effect on lateral and a pronounced negative effect on downward mobility. The effect of job opportunities turns out to be very large as the relative probability of upward mobility more than doubles when job opportunities improve by one-standard deviation. ${ }^{21}$ Workers in occupational labor markets are thus much more likely to change into an occupation with considerably higher status when there are many vacant jobs in the higher echelons of his or her OMC. Vice versa, jobs with considerably lower status are only rarely accepted under such circumstances. Although these findings may perhaps seem exiguous at first sight, they provide, to our knowledge, for the first time empirical evidence of the strong impact of job opportunities on between-firm status mobility at the level of a national labor market. This strong impact also becomes evident when we look at the findings for lateral and downward mobility as well. Job opportunities for lateral moves offering more or less the same status as the actual job (+/- 10\%) exert a very strong effect on lateral status mobility. The findings imply that when the number of such job vacancies increases by one standard deviation, the relative probability of a lateral move, again, is more than doubled. Motivational factors may act as triggers for such lateral moves as workers might seek new challenges after having worked in the same occupation for some time.

21 When calculating a model with standardized opportunity indicators, the respective hazard ratio amounts to 2.2 for upward mobility. 
The availability of vacancies in lower status jobs $(<10 \%)$ within a worker's OMC is important for upward and downward status mobility, but shows no effect on lateral mobility. The greater the number of such vacancies, the more likely it is that workers have to accept jobs with considerable lower status and the less likely are changes into jobs granting higher status. Although these effects are slightly weaker than for higher or equal-level job opportunities, they are substantial. ${ }^{22}$ Job loss, impending unemployment or inacceptable working conditions may force workers in OMCs where available jobs concentrate in occupations with lower status to accept occupational downward mobility.

Job vacancies in workers' current occupation play only a very limited role for status mobility. The weak negative effects indicate that this type of opportunity may slightly lower the probability to change occupations irrespective of the status direction. The effect for downward mobility is the only one that comes close to statistical significance (on the $10 \%$ level). Abundant job vacancies in the current job thus may help prevent downward moves but have little influence on other types of status mobility.

Overall, the strong and clear-cut effects are very much in line with our three main hypotheses. They support our general assumption that, in OLMs, the vacancies within a worker's OMC strongly determine occupational status mobility: Upward, lateral and downward mobility is highly contingent on the status of job opportunities in relation to the worker's current status. Before turning to the model comparison and presenting the findings regarding the conceptual validity of the concept of OMCs, we will complete the discussion of Table 2.

22 An increase of one standard deviation in the number of accessible jobs with lower status raises the hazard ratio of downward mobility by $70 \%$ and reduces the one for upward mobility by $30 \%$. 


\subsection{Job context and human capital}

The results for firm type show that in the public sector, lateral and (on the 10\%-level) downward mobility is significantly less widespread compared to the private sector. The likelihood for upward mobility does not differ between types of firm, however. For selected occupations, the public sector possibly offers opportunities for upward mobility by changing jobs between public sector companies (e.g., from the postal service to government administration). As for firm size, workers in large firms with more than 100 employees are a bit less likely to become laterally, but more likely to become upwardly mobile compared to their counterparts in smaller companies. Big firms' generally high reputation may make their employees sought-after job candidates for other employers, thus increasing the chances to change into a higher-status occupation. Self-employed people are generally less mobile, having usually established their company with a long-term perspective and considerable time investment. Similarly, workers with formal authority are also less mobile irrespective of the direction. The unexpected negative effect of formal authority on upward mobility might be due to higher mobility chances within firm-internal labor markets, which is not covered by our analysis. The probability for mobility of any direction also varies between broadly defined occupational groups, even when job opportunities have already been controlled for, suggesting differences in the prevalence of displacement between occupational groups. Their impact on mobility patterns may also be due to the possibly reduced discriminatory power of measuring job opportunities at the lower end of the scale (see endnote 8).

Net of other factors, people with higher education have a higher probability for upward, but a lower probability for lateral or downward mobility compared to the reference group with apprenticeship training. Workers with only compulsory schooling, by contrast, are less likely to experience upward mobility and increasingly so with time, reversing the corresponding descriptive finding of unskilled workers' higher upward mobility rate in absolute figures (Table 1). Stepwise modeling (results not shown) reveals that the initially 
positive relationship between compulsory schooling and upward/downward mobility disappears once job opportunities (for upward mobility) and the occupational group (for downward mobility) are controlled for. The pattern of results implies that unskilled workers' chances for occupational upward mobility are strongly linked with the business cycle, highlighting the importance of taking individual job opportunities into account. ${ }^{23}$ Further training after labor-market entry increases the likelihood for upward or lateral mobility, but does not affect downward mobility. As for labor market experience, workers are generally less mobile the more time they have already spent in the labor force. Spells out of the labor force for reasons other than training (e.g. unemployment, the birth of a child, illness) increase the likelihood of all types of occupational mobility.

Net of other factors, women generally have a lower probability to become mobile irrespective of the direction. This finding strongly deviates from the absolute mobility figures shown in Table 1. Stepwise modeling (results not shown) reveals, after controlling for job opportunities, a significant negative sex effect for upward mobility, suggesting that women are disadvantaged in situations of comparable job opportunities. ${ }^{24}$ These findings highlight the importance of taking individual job opportunities into account. Their neglect may explain the inconsistent results pertaining to gender and upward mobility chances in previous research (Carroll \& Mayer, 1986; Dekker, de Grip, \& Heijke, 2002; Hall, 2001; Johnston \& Lee, 2012). For downward mobility, stepwise modeling reveals that women's widespread labor

23 At a first glance, these findings contradict Gesthuizen and Wolber's (2010) findings of a structural (not cyclical) crowding-out of low educated Dutch men after 1980. This is possibly due to the different time periods under study. In Switzerland, unskilled workers of both birth cohorts studied in this paper have profited from a high labor demand in the peripheral segment of the labor market during the first few years of their career at the end of the 1960s and 1970s, respectively, increasing upward mobility chances. Skilled workers entered the labor market a few years later -- in the first half of the 1970s (older cohort) or 1980s (younger cohort) --, when the economic climate in Switzerland was considerably harsher and labor demand on the decline. Job opportunities were thus less abundant, leading to skilled workers lower upward mobility rate in absolute figures.

${ }^{24}$ The descriptive findings imply that women may have benefited from a labor shortage in potentially accessible occupations with higher status during the observed decades, resulting in equal absolute upward mobility figures. In the 1970s and 1980s, aggregate labor demand expanded particularly rapidly in female-dominated fields such as education, social services, and health (Sheldon, 1995). 
force interruptions account for their more frequent loss of occupational status in absolute figures (Table 1).

Despite lower absolute figures of occupational mobility due to a shorter observation span (Table 1), the younger birth cohort has a higher probability for upward and lateral status mobility once job opportunities, the job context, and human capital are controlled for. The emergence of the new information technologies in Switzerland at the beginning of the 1980s, when the younger cohort entered the labor market, may be the reason.

\subsection{Explanatory power of the concept of OMCs}

Table 3 shows the model comparison, testing the explanatory power of the concept of OMCs. For upward and lateral mobility, model 5 with four opportunity indicators capturing job vacancies within workers' OMCs does indeed fit best by far. BIC values are considerably lower (-101 and -87) compared to the next best model (no. 4). Further support is provided by the finding that the effects are almost cut in half when we employ opportunity indicators that neglect the inaccessibility of vacancies outside the worker's OMC. For downward mobility, model 4 including opportunity indicators which differentiate vacant jobs by status, but not by OMC, yields a similar or even slightly superior fit (-4) compared to Model 5. The reason probably is that downward mobility often leads into the unskilled segment, which is, by definition, not segmented on the basis of occupational certificates. Hence, it does not come much as a surprise that the incorporation of accessibility-weights in the opportunity indicators does not further improve our model. Model 3, including the aggregated total number of vacant jobs (i.e., the business cycle), and model 2 , without any vacancy indicators, invariably show a clearly inferior fit. This suggests, first, that macro-level measures of job opportunities are not well suited to explain status mobility in OLMs. Second, the findings support our hypothesis that, in OLMs, status mobility is typically channeled through OMCs and that the statuses of the vacant jobs within the OMC define the individual opportunity structure for upward, 
lateral, and downward mobility. These opportunity structures are particularly relevant for upward and lateral status mobility.

\section{Conclusion}

This paper examined how job opportunities, defined as the vacancies within a worker's OMC, affect between-firm occupational status mobility at the level of individual labor-market participants in an OLM and tested the conceptual validity of the newly introduced notion of OMCs. The approach chosen here thus aimed at contributing to the field of career mobility both theoretically and empirically.

Our paper shows for the occupationally segmented Swiss labor market that there are strong and clear-cut relationships between different types of job opportunities and betweenfirm status mobility At first glance, this finding may seem obvious. However, it is highly relevant for the following reasons: To our knowledge, this paper is the first one to show empirically that the likelihood of inter-firm status mobility in an OLM depends on the number and status of job opportunities suited for workers with given credentials and characteristics. Most importantly, our findings shed light on how job opportunities affect mobility in the labour market. In order to capture the dominant mechanisms, we have proposed the concept of OMCs. It outlines the preconditions for upward, lateral, and downward status mobility in OLMs and specifies clusters of relatively permeable occupational subsegments, where mobility is likely to be expected. Model comparison of alternative conceptualizations of job opportunities confirmed the validity of the proposed concept.

Our empirical findings provide strong evidence that in labour markets with a strong occupational segmentation, the impact of vacancies on status mobility is channeled through OMCs. Two aspects need to be highlighted. First, in line with the general claim of the OMC concept, vacancies affect mobility chances of workers equipped with a given occupationspecific credential only under condition that these vacancies are located in one of the small 
number of occupational subsegments accessible with the credential at issue. These findings are in accordance both with the assumption of a generally strong occupational segmentation of the Swiss labor market and the idea of a somewhat increased permeability between neighboring subsegments as posited by the concept of OMCs. Second, our empirical analyses are in line with the expectation that the direction of status mobility (i.e., the likelihood of upward, lateral, and downward mobility) is highly contingent upon the status of the vacant jobs within a worker's OMC.

Given that the long-term development of the number of job opportunities within different occupational subsegments is impossible to anticipate at the time when individuals enter training, status mobility is difficult to plan for individual workers and remains highly dependent on unforeseeable structural forces responsible for job creation. Our findings thus lend clear support to a structuralist notion of social stratification, emphasizing the role of job opportunities and occupational labor market segmentation.

Our paper also shows that the inclusion of elaborate measures for job opportunities modifies the effect of individual characteristics on occupational mobility. This was for example revealed when examining the upward mobility chances of workers with different educational backgrounds or gender. Compared to workers with certified vocational or professional skills, unskilled ones were more dependent on higher status job opportunities when they wanted to become upwardly mobile. In the same vein, women were only on an equal footing with men regarding upward mobility chances under conditions of a labor shortage in potentially accessible occupations with higher status. These findings attest to the subtle ways in which the status of job vacancies within OMCs shapes occupational status trajectories in an OLM. It is an open question whether vacant jobs within OMCs are as important for explaining occupational mobility in less segmented labor markets such as, for example, in the USA or Sweden. Theoretical considerations of Spilerman (1977) and Kerckhoff (1995) suggest that career lines similar to what we described as OMCs may exist 
also in other types of labor markets - particularly in craft occupations and some professions. However, it is quite likely that in less occupationally segmented labor markets, individual job opportunities and the concomitant mobility pathways depend more on the level of educational attainment and the amount and type of work experience than on occupational credentials. Comparative research is needed to shed light on this issue.

The research presented here highlights the importance of taking labor market structures into account when conceptualizing job opportunities and analyzing their impact on career mobility. The empirical findings provide unambiguous evidence that - at least in OLMs -aggregate measures of job opportunities at the level of the entire labor market do not suffice to explain status mobility.

Some issues remain unanswered, however. Based on larger sample sizes than available here, future research may pursue the question of how the significance of skills and other individual characteristics for status mobility may shift when the usually ignored job opportunities are controlled for conveniently. Another promising avenue for future research is the question of whether different groups of workers profit unequally from a good offer of job opportunities. 


\section{APPENDIX A. Measurement of individual job opportunities}

Four steps are needed to construct indicators of individual job opportunities. First, we classify all job advertisements by preferred gender, age, and required experience and aggregate the number of respective job openings by year and occupation. This procedure yields the number of advertised jobs per year and occupation for eight groups of prospective employees: Men and women younger or older than 30 years with or without experience. The job ads were weighted in order to compensate for small differences in the selection probability.

Second, the information provided in job advertisements is in many instances not sufficient to infer the educational requirements necessary to apply for the advertised jobs with reasonable prospect of success. Employers often take occupation-specific credentials for granted and do not explicitly list them in advertisements. We therefore need external information on skill barriers in the Swiss labor market. The Swiss Census of 1970, 1980, and 1990 provide the necessary information as they include matrices of occupation-specific credentials and occupations held. The individual cells of these matrices show the degree to which given educational credentials are linked to given occupations. For each cell of the matrices, we compute the transition probability according to the following formula:

$\mathrm{w}_{\mathrm{ab}}=\mathrm{x}_{\mathrm{ab}} / \mathrm{x}_{\mathrm{a}}$

$\mathrm{w}_{\mathrm{ab}}$ transition probability of occupation-specific credential $a$ to occupational activity $b$

$\mathrm{x}_{\mathrm{ab}} \quad$ Number of individuals equipped with occupation-specific credential $a$ and active in occupation $b$

$\mathrm{x}_{\mathrm{a}} \quad$ Total number of individuals equipped with occupation-specific credential $a$

These transition probabilities may be interpreted as estimates of the accessibility of jobs within a given occupation for people with given occupation-specific credentials. Most 
transition probabilities are low, indicating that transitions between most occupations are rare due to occupational segmentation.

Third, we construct job opportunity indicators by linking the job-advertisement data with the transition probabilities (= accessibility weights) according to the following formula (exemplified by the number of vacancies with at least 10 percent higher status than the current (or last) occupation):

$$
O_{a b i j}=\sum_{s=s(b)}^{S}\left(w_{a s} \cdot n_{s j i}\right)+\sum_{s=s(b)}^{S}\left(w_{o s} \cdot n_{s j i}\right)
$$

where:

$O_{i a b j} \quad$ Total number of advertised jobs in year $j$ weighted by accessibility and with a status score which is at least $10 \%$ higher than the status of the occupation $b$ held in year $j$ for individuals with occupation-specific credential $a$ belonging to group $i$

$s \quad$ Index of status rank of a given occupation within a total of $S$ occupations

$s(b) \quad$ Status rank of the lowest-ranking occupation with a status score which is at least $10 \%$ higher than the currently held occupation $b$

$w_{a s} \quad$ Transition rate of skilled workers holding occupation-specific credential $a$ into an occupation with status rank $s^{25}$

$n_{s i j} \quad$ Number of published job vacancies in year $j$ for occupation with status rank $s$ which are accessible for individuals belonging to group $i$

$w_{o s} \quad$ Transition rate of unskilled workers (no occupation-specific credential) into an occupation with status rank $s^{18}$

This formula states that we multiply the number of advertised jobs with at least $10 \%$ higher status per occupation and year with the occupation-specific transition probability of individuals with a given credentials. ${ }^{26}$ Thereafter, we aggregate the estimated opportunity per occupation-specific credential (including the state 'no occupation-specific credential').

25 To simplify the formula, we have neglected that transition rates may also vary between occupations with the same status.

26 Job vacancies in the 1960s (1961-1970) are linked with the matrix of the 1970 Swiss Census; those in the 1970s with the 1980 Swiss Census; and those in the 1980s with the respective matrix of 1990. 
Finally, assuming that unskilled jobs are accessible for skilled workers, we add, a constant measuring the aggregated job vacancies of people without any occupation-specific credential to enter the occupation in question. ${ }^{27}$ This calculation is repeated for each calendar year and for each of the eight specified groups of prospective employees. This yields the total annual number of job openings with more than $10 \%$ higher status suited for workers with a given occupational certificate, work experience (with /without), for men and women and for workers under (and above) thirty years of age. The same procedure is repeated for job opportunities with more than $10 \%$ lower, $0-10 \%$ higher or $1-10 \%$ lower status, and in the current (or last) occupation. The resulting four indicators add up to the total of accessability weighted job vacancies within a workers' OMCs for which she or he brings along the necessary prerequisites to qualify for the pool of potential job candidates.

Fourth, we match the individually customized job opportunity indicators with the individual career history data on the basis of respondent's occupation-specific credentials and the occupation held at a given point in time as well as the individual characteristics defining the eight groups of workers (experience, age, and sex).

27 By doing this we avoid the rather unrealistic situation of unskilled workers without any occupational credentials having better job opportunities compared to workers with credentials. 
APPENDIX B: Descriptives

[Table Alabout here] 


\section{References}

Allmendinger, J. (1989). Career mobility dynamics. A comparative analysis of the United States, Norway, and West Germany. Berlin: Max-Planck-Institut für Bildungsforschung.

Becker, G.S. (1975). Human capital. New York/London: Columbia University Press.

Becker, R. (1993). Staatsexpansion und Karrierechancen. Berufsverläufe im öffentlichen Dienst und in der Privatwirtschaft. Frankfurt a.M./New York: Campus.

BFS (2008). Regionale Disparitäten in der Schweiz. Schlüsselindikatoren. Neuchâtel: SFSO.

Blossfeld, H.-P. (1987). Karriereprozesse im Wandel der Arbeitsmarktstruktur - ein dynamischer Ansatz zur Erklärung intragenerationaler Mobilität. Mitteilungen aus der Arbeitsmarkt- und Berufsforschung, 20, 74-88.

Blossfeld, H.-P., Golsch, K., \& Rohwer, G. (2007). Event history analysis with Stata. Mahwah/New Jersey/London: Lawrence Erlbaum Associates.

Blossfeld, H.-P., Hamerle, A., \& Mayer, K.U. (1986). Ereignisanalyse. Statistische Theorie und Anwendung in den Wirtschafts- und Sozialwissenschaften. Frankfurt a.M./New York: Campus.

Blossfeld, H.-P., \& Mayer, K.U. (1988). Labor market segmentation in the Federal Republic of Germany: an empirical study of segmentation theories from a life course perspective. European Sociological Review, 4, 123-140.

Blossfeld, H.-P., \& Rohwer, G. (2002). Techniques of event history modeling. New approaches to causal analysis. Mahwah/New Jersey/London: Lawrence Erlbaum Associates.

Brüderl, J., \& Ludwig-Mayerhofer, W. (1994). Aufbereitung von Verlaufsdaten mit zeitveränderlichen Kovariaten mit SPSS. ZA-Information, 34, 79-105.

Buchmann, M., Kriesi, I., \& Sacchi, S. (2009). Labor-market, job opportunities and transitions to self-employment: evidence from Switzerland from the mid-1960s to the late 1980s. European Sociological Review, 25, 569-583. 
Buchmann, M., \& Sacchi, S. (1995). Mehrdimensionale Klassifikation beruflicher Verlaufsdaten. Eine Anwendung auf Berufslaufbahnen zweier Schweizer Geburtskohorten. Kölner Zeitschrift für Soziologie und Sozialpsychologie, 47, 413-442.

Buchmann, M., \& Sacchi, S. (1997). Berufsverlauf und Berufsidentität im sozio-technischen Wandel: Konzeption, Methodik und Repräsentativität einer retrospektiven Befragung der Geburtsjahrgänge 1949-51 und 1959-61. Zürich: Eidgenössische Technische Hochschule, Professur für Soziologie.

Buchmann, M., Sacchi, S., \& Kriesi, I. (2002). Qualifications, dynamics of skill demand, and career outcomes. In F. Horváth (Ed.), Forum Bildung und Beschäftigung. Workshop Dokumentation (pp. 229-241). Bern: Universität Bern.

Buchs, H., Müller, B., Buchmann, M. (2015, in print)). Qualifikationsnachfrage und Arbeitsmarkteintritt in der Schweiz: Arbeit im erlernten Beruf, Berufswechsel oder Arbeitslosigkeit. Kölner Zeitschrift für Soziologie und Sozialpsychologie 67(4).

Carroll, G.R., \& Mayer, K.U. (1986). Job-shift patterns in the Federal Republic of Germany: the effects of social class, industrial sector, and organizational size. American Sociological Review, 51, 323-341.

Chase, I.D. (1991). Vacancy chains. Annual Review of Sociology, 17, 133-154.

Cramer, U. (1990). Probleme bei der Besetzung von offenen Stellen. Ergebnisse einer Betriebsbefragung. Mitteilungen aus der Arbeitsmarkt- und Berufsforschung, 23, 246-254.

Dekker, R., de Grip, A., \& Heijke, H. (2002). The effects of training and overeducation on career mobility in a segmented labour market. International Journal of Manpower, 23, 106-125.

DiPrete, T.A., de Graaf, P.M., Luijkx, R., Tåhlin, M., \& Blossfeld, H.-P. (1997). Collectivist versus individualist mobility regimes? Structural change and job mobility in four countries. American Journal of Sociology, 103, 318-358. 
DiPrete, T.A., \& Krecker, M.L. (1991). Occupational linkages and job mobility within and across organizations. In R. Althauser \& M. Wallace (Eds.), Research in social stratification and mobility. A research annual. (pp. 91-131). Greenwich: Jai Press.

DiPrete, T.A., \& Nonnemaker, K.L. (1997). Structural change, labor market turbulence, and labor market outcomes. American Sociological Review, 62, 386-404.

Döpke, J. (1995). Konjunkturzyklen im Dienstleistungssektor. Die Weltwirtschaft, 1995, 311-324.

Dörfler, L., \& van de Werfhorst, H. G. (2009). Employer's demand for qualifications and skills. Increased merit selection in Austria, 1985 to 2005. European Societies, 11(5), $697-$ 721

Fujiwara-Greve, T., \& Greve, H.R. (2000). Organizational ecology and job mobility. Social Forces, 79, 547-568.

Gelissen, J., \& de Graaf, P. M. (2006). Personality, social background, and occupational career success. Social Science Research, 35, 702-726.

Gesthuizen, M., \& Wolbers, M. H. J. (2010). Employment transitions in the Netherlands, 1980-2004: Are low educated men subject to structural or cyclical crowding out? Research in Social Stratification and Mobility, 28, 437-451.

Hachen, D.S. (1988). Industrial labor markets and job mobility rates. In A.L. Kalleberg (Ed.), Research in social stratification and mobility 7 (pp. 35-68). Greenwich: Jai Press.

Hachen, D.S.J. (1992). Industrial characteristics and job mobility rates. American Sociological Review, 57, 39-55.

Halaby, C.N. (1988). Action and information in the job mobility process: the search decision. American Sociological Review, 53, 9-25.

Hall, A. (2001). Berufliche Karrieremobilität in Deutschland und Grossbritannien. Gibt es Differenzen zwischen Frauen und Männern? In P.A. Berger \& D. Konietzka (Eds.), Die 
Erwerbsgesellschaft. Neue Ungleichheiten und Unsicherheiten (pp. 213-249). Opladen: Leske + Budrich

Harrison, R.J. (1988). Opportunity models: Adapting vacancy models to national occupational structures. In A.L. Kalleberg (Ed.), Research in social stratification and mobility 7 (pp. 333). Greenwich: Jai Press.

Haveman, H.A., \& Cohen, L.E. (1994). Ecological dynamics of careers: the impact of organizational founding, dissolution, and merger on job mobility. American Journal of Sociology, 100, 104-152.

Jackson, M., Goldthorpe, J. H., \& Mills, C. (2005). Education, employers and class mobility. Research in Social Stratification and Mobility, 23, 3-33.

Johnston, D. W., \& Lee, W.-S. (2012). Climbing the job ladder: New evidence of gender inequity. Industrial Relations 51, 129-151.

Kaiser, M. (1983). Berufliche Flexibilität - Konzeption, Befunde, Schlussfolgerungen, Kritik und Forschungsperspektiven. In D. Mertens (Ed.), Konzepte der Arbeitsmarkt- und Berufsforschung. Eine Forschungsinventur des IAB (pp. 357-444). Nürnberg: Institut für Arbeitsmarkt- und Berufsforschung der Bundesanstalt für Arbeit.

Kalmijn, M., \& Luijkx, R. (2006). Changes in women's employment and occupational mobility in the Netherlands: 1955 to 2000. In H.-P. Blossfeld \& H. Hofmeister (Eds.), Globalization, uncertainty and women's careers: an international comparison (pp. 84113). Cheltenham: Edward Elgar.

Kerckhoff, A.C. (1995). Institutional arrangements and stratification processes in industrial societies. Annual Review of Sociology, 15, 323-347.

Kriesi, I. Buchmann, M., \& Sacchi, S. (2010). Variation in job opportunities for men and women in the Swiss labor market 1963-1989. Research in Social Stratification and Mobility 28:309-323. 
Kye, B. (2008). Internal labor markets and the effects of structural change: Job mobility in Korean labor markets between 1998 and 2000. Research in Social Stratification and Mobility, 26, 15-27.

Le Grand, C., \& Tahlin, M. (2002). Job mobility and earnings growth. European Sociological Review, 18, 381-400.

Leibundgut, H. (1986). Die Bedeutung der beruflichen Mobilität als arbeitsmarktlicher Ausgleichsprozess. Eine empirische Untersuchung aufgrund der Eidgenössischen Volkszählung 1980. Bern: Peter Lang.

Levy, R., Joye, D., Guye, O., \& Kaufmann, V. (1997a). Tous égaux? De la stratification aux représentations. Zürich: Seismo.

Lippmann, S., \& Rosenthal, J.E. (2008). Do displaced workers lose occupational prestige? Social Science Research, 37, 642-656.

Malo, M. A., \& Muñoz-Bullón, F. (2008). Long-term effects of involuntary job separations on labour careers. The Journal of Socio-Economics, 37, 767-788.

Mayer, K.U., \& Carroll, G.R. (1987). Jobs and classes: structural constraints on career mobility. European Sociological Review, 3, 14-38.

McBrier, D.B., \& Wilson, G. (2004). Going down? Race and downward occupational mobility for white-collar workers in the 1990s. Work and Occupations, 31, 283-322.

Miller, R.K. (1982). Labor market structure and career occupational status mobility: a theoretical model. Sociological Inquiry, 52, 152-163.

Müller, B. \& Schweri, J. (2015). 'How specific is apprenticeship training? Evidence from inter-firm and occupational mobility after graduation'. Oxford Economic Papers 67(4): 1057-1077.

OECD (1994). The OECD jobs study. Evidence and explanations part I: labour market trends and underlying forces of change. Paris: OECD. 
Raftery, A.E. (1995). Bayesian model selection in social research. Sociological Methodology, 25, 111-163.

Reyher, L., Spitznagel, E., \& Kretschmer, G. (1990). Das gesamtwirtschaftliche Stellenangebot. Mitteilungen aus der Arbeitsmarkt- und Berufsforschung, 23, 347-327.

Rosenfeld, R.A. (1992). Job mobility and career processes. Annual Review of Sociology, 18, $39-61$.

Sacchi, S. (2014). 'Lange Messreihen zur Entwicklung des Stellenangebots der Schweizer Wirtschaft: Kombinierter Presse-Online-Index'. 'SMM-Working-Paper 2014/1' Swiss Job Monitor: University of Zurich.

Sacchi, S., Salvisberg, A., \& Buchmann, M. (2005). Long-term dynamics in employer's demand for skills: Switzerland 1950-2000. In H. Kriesi, P. Farago, M. Kohli \& M. ZarinNejadan (Eds.), Contemporary Switzerland: revisiting the special case (pp. 105-134). Houndmills: Palgrave Macmillan.

Schulz, W., Maas, I., \& Leeuwen, M. H. D. v. (2014). Employer's choice - selection through job advertisements in the nineteenth and twentieth centuries. Research in Social Stratification and Mobility, 36, 49-68.

Sengenberger, W. (1987). Struktur und Funktionsweise von Arbeitsmärkten. Die Bundesrepublik Deutschland im internationalen Vergleich. Frankfurt a.M./New York: Campus.

Sheldon, G. (1995). Die berufliche Flexibilität im Spiegel der Zeit. Bern: Bundesamt für Statistik.

Sheldon, G. (2005). Der berufsstrukturelle Wandel der Beschäftigung in der Schweiz. Neuchâtel: Federal Statistical Office.

Sicherman, N., \& Galor, O. (1990). A theory of career mobility. Journal of Political Economy, 98, 169-192. 
Solga, H. (2001). Longitudinal surveys and the study of occupational mobility: panel and retrospective design in comparison. Quality \& Quantity, 35, 291-309.

Sørensen, A.B., \& Tuma, N.B. (1981). Labor market structures and job mobility. In D.J. Treiman \& R.V. Robinson (Eds.), Research in social stratification and mobility. A research annual (pp. 67-94). Greenwich: Jai Press.

Spilerman, S. (1977). Labor market structure, and socioeconomic achievement. American Journal of Sociology, 83, 551-593.

Stewman, S., \& Konda, S.L. (1983). Careers and organizational labor markets: demographic models of organizational behaviour. American Journal of Sociology, 88, 637-685.

Stovel, K., \& Savage, M. (2006). Mergers and Mobility: Organizational Growth and the Origins of Career Migration at Lloyds Bank. American Journal of Sociology, 111, 10801121.

Treiman, D.J. (1977). Occupational prestige in comparative perspective. New York: Academic Press.

Uunk, W., Mach, B., \& Mayer, K.U. (2005). Job mobility in the former East and West Germany: the effects of state-socialism and labor market composition. European Sociological Review, 21, 393-408.

Wilson, G. (2009). Race and exits from white collar jobs: differences in downward mobility processes among African, American, Latin, and white males. Research in Social Stratification and Mobility, 27, 143-156.

Wilson, G., \& Roscigno, V. J. (2010). Race and downward mobility from privileged occupations: African American/White dynamics across the early work-career. Social Science Research, 39, 67-77.

Wolbers, M. (2008). Increasing labor market instability among young people? Labor market entry and early career development among school-leavers in the Netherlands since the mid-1980s. In H.-P. Blossfeld, S. Bucholz, E. Bukodi \& K. Kurz (Ed.), Young workers, 
Globalization and the labor market: Comparing early working life in eleven countries. Cheltenham UK/Northampton, MA: Edward Elgar.

Yamaguchi, K. (1991). Event history analysis. Newbury Park/London/New Dehli: Sage Publications.

Yu, W.-h. (2010). Enduring an economic crisis: The Effect of macroeconomic shocks on intragenerational mobility in Japan. Social Science Research, 39, 1088-1107.

Zühlke, S., \& Goedicke, A. (2000). Mobilität oder Immobilität? Zur Bedeutung interner Arbeitsmärkte in beiden deutschen Staaten vor 1989. Kölner Zeitschrift für Soziologie und Sozialpsychologie, 52, 81-95. 
Figure 1: OMCs in occupationally segmented labor markets

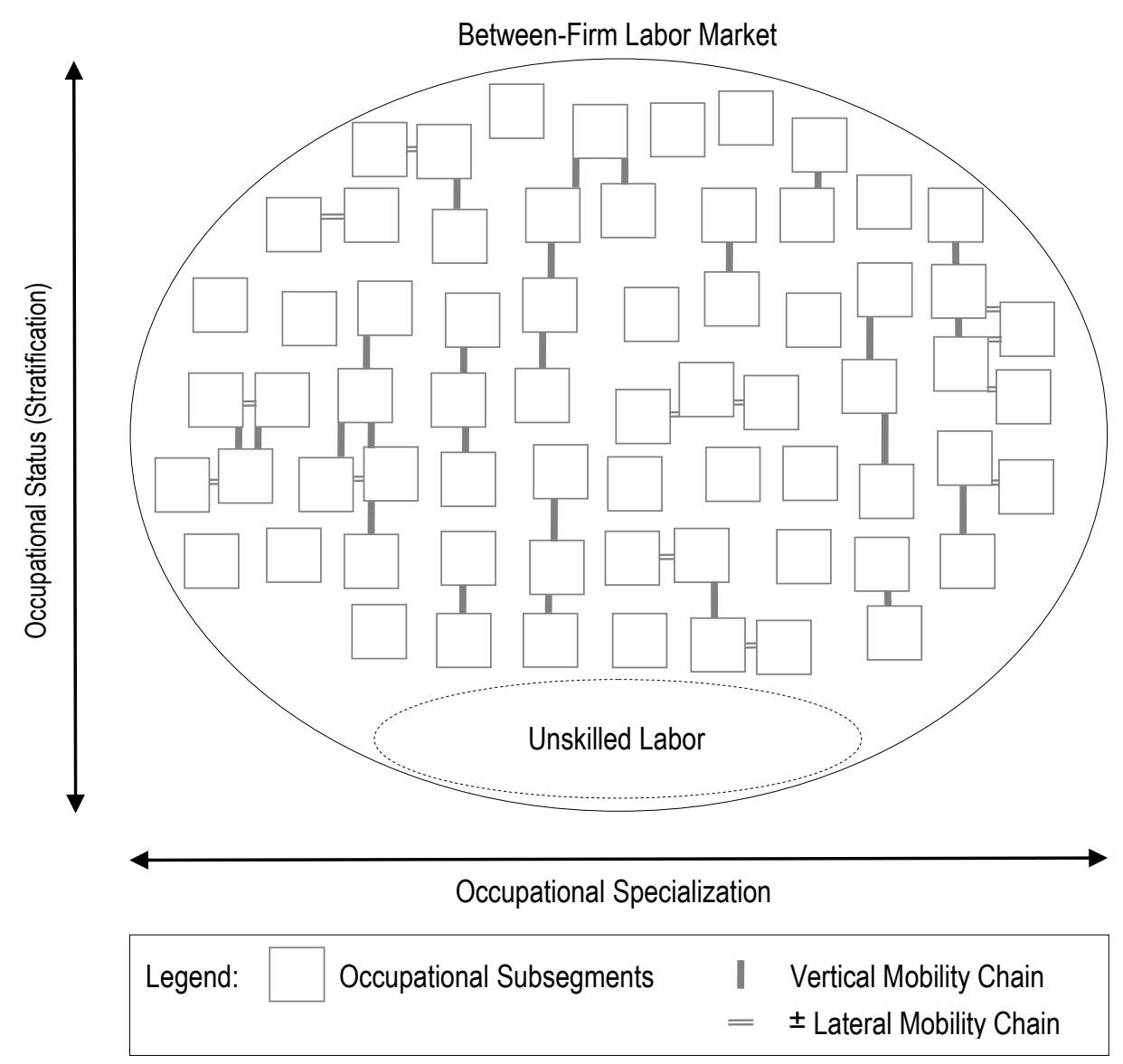


Table 1. Distribution of Events for Time-constant Covariates: Row percentage ${ }^{a}$

\begin{tabular}{lllll}
\hline \hline & Upward & Lateral & Downward & No mobility \\
\hline Sex & & & & \\
$\quad$ Men & 29.6 & 18.6 & 16.3 & 35.5 \\
$\quad \begin{array}{l}\text { Women } \\
\text { Birth cohort }\end{array}$ & 29.1 & 10.8 & 22.7 & 37.4 \\
$\quad$ 1949-51 & & & & \\
$\quad$ 1959-61 & 31.4 & 16.1 & 21.3 & 31.3 \\
Education & 27.5 & 13.9 & 17.6 & 41.0 \\
$\quad$ Lower Secondary & 38.2 & 11.4 & 27.9 & \\
$\quad$ Apprenticeship & 28.0 & 18.1 & 17.2 & 36.7 \\
$\quad$ Higher Education & 25.2 & 10.8 & 17.1 & 46.9 \\
\hline
\end{tabular}

${ }^{\mathrm{a}}$ Based on with the number of respondents, $\mathrm{N}=2155 / 2200 / 2200$ 
Table 2. Determinants of Occupational Status Mobility ${ }^{*}$

\begin{tabular}{|c|c|c|c|c|c|c|}
\hline \multirow[t]{2}{*}{ Cox regression } & \multicolumn{2}{|c|}{ Upward } & \multicolumn{2}{|c|}{ Lateral } & \multicolumn{2}{|c|}{ Downward } \\
\hline & $\mathrm{B}$ & SE & $\mathrm{B}$ & SE & $\mathrm{B}$ & SE \\
\hline \multicolumn{7}{|l|}{ Job opportunities } \\
\hline No. job opps. with more than $10 \%$ higher status & $0.80^{* * * *}$ & 0.07 & -0.08 & 0.09 & $-0.38^{* * *}$ & 0.10 \\
\hline No. job opps. with $+/-10 \%$ status & 0.02 & 0.10 & $0.90^{* * *}$ & 0.11 & $-0.38^{*}$ & 0.15 \\
\hline No. job opps. with more than $10 \%$ lower status & $-0.57^{* * *}$ & 0.08 & 0.03 & 0.15 & $0.54^{* * *}$ & 0.09 \\
\hline No. job opps. in current (last) occupation & -0.11 & 0.07 & -0.08 & 0.09 & $-0.20^{+}$ & 0.11 \\
\hline \multicolumn{7}{|l|}{ Job context } \\
\hline Firm type: private & 0.07 & 0.13 & $0.43^{*}$ & 0.20 & $0.33^{+}$ & 0.19 \\
\hline Firm size > 100 employees & $0.22^{*}$ & 0.10 & $-0.24^{+}$ & 0.15 & 0.08 & 0.10 \\
\hline Self-employed & $-1.34^{* * *}$ & 0.39 & $-1.87^{* *}$ & 0.61 & $-1.23^{* *}$ & 0.42 \\
\hline Formal authority & $-0.45^{* * *}$ & 0.08 & $-0.68^{* * *}$ & 0.17 & $-0.41^{* *}$ & 0.16 \\
\hline Values missing & 0.06 & 0.57 & -0.40 & 0.57 & -0.11 & 0.37 \\
\hline \multicolumn{7}{|l|}{ Occupational group (office / administrative clerks) } \\
\hline Agricultural Occupations & -0.26 & 0.32 & $-1.26^{+}$ & 0.72 & $0.93^{*}$ & 0.47 \\
\hline Textile occupations & -0.48 & 0.44 & -0.58 & 1.06 & $1.47^{*}$ & 0.68 \\
\hline Wood and paper occupations & -0.55 & 0.47 & $-1.43^{*}$ & 0.67 & -0.36 & 1.04 \\
\hline Higher service sector occupations & $1.42^{* *}$ & 0.49 & & & 0.85 & 0.74 \\
\hline Restaurant / housekeeping occupations & -0.02 & 0.30 & -0.14 & 0.39 & $1.43^{* * *}$ & 0.32 \\
\hline Cleaning/personal hygiene occupations & $-1.00^{* * * *}$ & 0.31 & -0.12 & 0.48 & $1.13^{* *}$ & 0.44 \\
\hline Teaching, social, counseling occupations & -0.25 & 0.21 & $0.67^{+}$ & 0.35 & 0.31 & 0.37 \\
\hline Other occupations & -0.35 & 0.22 & -0.03 & 0.21 & 0.25 & 0.32 \\
\hline \multicolumn{7}{|l|}{ Human capital and control variables } \\
\hline \multicolumn{7}{|l|}{ Education at labor market entry (apprenticeship) } \\
\hline Compulsory education & $-0.53^{* *}$ & 0.17 & 0.17 & 0.24 & 0.24 & 0.17 \\
\hline Higher education & $0.48^{* * *}$ & 0.12 & $-0.45^{*}$ & 0.19 & $-0.32^{*}$ & 0.14 \\
\hline Compulsory education $*$ time & $-1.78^{* * *}$ & 0.12 & & & & \\
\hline Higher education $*$ time & & & $-0.80^{* * *}$ & 0.16 & & \\
\hline Training spell after labor market entry & $0.65^{* * *}$ & 0.12 & $0.58^{*}$ & 0.26 & 0.10 & 0.18 \\
\hline Labor market experience & $-0.01^{*}$ & 0.00 & $-0.01^{* *}$ & 0.00 & $-0.01^{*}$ & 0.00 \\
\hline Spell out of labor force & $0.51^{* *}$ & 0.18 & $0.98^{* * *}$ & 0.23 & $0.69^{* * *}$ & 0.16 \\
\hline Sex: women & $-0.81^{* * *}$ & 0.13 & $-1.31^{* * *}$ & 0.18 & $-0.66^{* * *}$ & 0.16 \\
\hline Sex $*$ time & & & $-1.36^{* * *}$ & 0.12 & $-1.74^{* * *}$ & 0.08 \\
\hline Birth cohort: 1959-61 & $0.31^{* *}$ & 0.11 & $0.25^{*}$ & 0.12 & -0.09 & 0.14 \\
\hline $\mathrm{N}$ & 2155 & & 2200 & & 2200 & \\
\hline df & 25 & & 25 & & 25 & \\
\hline Events & 640 & & 329 & & 424 & \\
\hline Episodes & 22227 & & 22705 & & 22705 & \\
\hline Log pseudo-likelihood & -4093 & & -2131 & & -2682 & \\
\hline Wald Chi2 & $1582^{* * *}$ & & $1869^{* * *}$ & & $2795^{* * *}$ & \\
\hline
\end{tabular}

$+\mathrm{p} \leq .10 / * \mathrm{p} \leq .05 / * * \mathrm{p} \leq .01 / * * * \mathrm{p} \leq .001$ (two tailed)

${ }^{*}$ This model is referred to as Model 5 in Table 3 
Table 3. Model comparison: Coefficients (b, p, (se)) and goodness of fit measures ${ }^{2}$

\begin{tabular}{|c|c|c|c|}
\hline & Upward & Lateral & Downward \\
\hline \multicolumn{4}{|c|}{$\begin{array}{l}\text { Model } 5 \text { (see Table 2): } \\
\text { Includes opportunity indicators weighted by accessibility }{ }^{1}\end{array}$} \\
\hline No. job opps. with more than $10 \%$ higher status & $0.80^{* * *}(0.07)$ & $-0.08 \quad(0.09)$ & $-0.38^{* * *}(0.10)$ \\
\hline No. job opps. with $+/-10 \%$ status & $0.02 \quad(0.10)$ & $0.90^{* * * *}(0.11)$ & $-0.38^{*} \quad(0.15)$ \\
\hline No. job opps. with more than $10 \%$ lower status & $-0.57^{* * * *}(0.08)$ & $0.03 \quad(0.15)$ & $0.54^{* * *}(0.09)$ \\
\hline No. job opps. in current (last) occupation & $-0.11 \quad(0.07)$ & $(0.09)$ & $-0.20^{+} \quad(0.11)$ \\
\hline & 25 & 25 & 25 \\
\hline Log pseudo-likelihood & -4093 & -2131 & -2682 \\
\hline AIC & 8237 & 4312 & 5414 \\
\hline $\mathrm{BIC}$ & $8378^{*}$ & 4453 & 5555 \\
\hline \multicolumn{4}{|c|}{$\begin{array}{l}\text { Model 4: } \\
\text { Includes opportunity indicators without accessibility weights }\end{array}$} \\
\hline No. jobs with more than $10 \%$ higher status & $0.45^{* * *}(0.05)$ & $-0.27^{* * *}(0.08)$ & $-0.24^{* * *}(0.07)$ \\
\hline No. jobs with $+/-10 \%$ status & $-0.11 \quad(0.09)$ & $0.50^{* *}(0.17)$ & $-0.21 \quad(0.13)$ \\
\hline No. jobs with more than $10 \%$ lower status & $-0.24^{* * *}(0.05)$ & $-0.17^{*} \quad(0.07)$ & $0.34^{* * *}(0.07)$ \\
\hline No. jobs in current (last) occupation & $-0.06 \quad(0.06)$ & $-0.12 \quad(0.10)$ & $-0.09 \quad(0.10)$ \\
\hline df & 25 & 25 & 25 \\
\hline Log pseudo-likelihood & -4144 & -2174 & -2680 \\
\hline AIC & 8338 & 4398 & 5409 \\
\hline $\mathrm{BIC}$ & 8479 & 4540 & 5551 \\
\hline \multicolumn{4}{|c|}{$\begin{array}{l}\text { Model 3: } \\
\text { Includes total number of vacant jobs without accessibility } \\
\text { weights }\end{array}$} \\
\hline No. jobs total & $0.06^{* *}(0.02)$ & $(0.03)$ & $(0.03)$ \\
\hline $\mathrm{df}$ & 22 & 22 & 22 \\
\hline Log pseudo-likelihood & -4245 & -2182 & -2731 \\
\hline AIC & 8533 & 4407 & 5505 \\
\hline BIC & 8658 & 4532 & 5630 \\
\hline \multicolumn{4}{|l|}{ Model 2: Includes no opportunity indicators } \\
\hline df & 21 & 21 & 21 \\
\hline Log pseudo-likelihood & -4249 & -2182 & -2732 \\
\hline AIC & 8541 & 4406 & 5506 \\
\hline BIC & 8659 & 4524 & 5625 \\
\hline \multicolumn{4}{|l|}{ Model 1: Baseline model without covariates } \\
\hline df & 0 & 0 & 0 \\
\hline Log pseudo-likelihood & -4548 & -2358 & -3040 \\
\hline AIC & 9096 & 4716 & 6080 \\
\hline BIC & 9096 & 4716 & 6080 \\
\hline
\end{tabular}

\footnotetext{
${ }^{1}$ Model displayed in Table 2 *grey: best model $\quad+\mathrm{p} \leq .10 / * \mathrm{p} \leq .05 / * * \mathrm{p} \leq .01 / * * * \mathrm{p} \leq .001$ (two tailed)
}

${ }^{2}$ There is lacking consensus in the literature on what $\mathrm{N}$ should be when calculating BIC' for cox models. Possible options are the number of individuals, the number of events or the number of spells (Raftery, 1995, p. 137; see also http://www.stata.com/help.cgi?bic_note). Calculations in Table 3 are based on the number of individuals $(\mathrm{N}=2116)$. A comparison of the BIC' calculated with the number of individuals, spells and events respectively yielded no substantial differences. 
Table A1: Weighted means and standard deviations ${ }^{\mathrm{a}}$

\begin{tabular}{|c|c|c|}
\hline & Mean & SD \\
\hline \multicolumn{3}{|l|}{ Dependent Variables } \\
\hline Upward mobility & 0.029 & 0.166 \\
\hline Lateral mobility & 0.014 & 0.119 \\
\hline Downward mobility & 0.019 & 0.136 \\
\hline \multicolumn{3}{|l|}{ Job Opportunities } \\
\hline No. job opps. with more than $10 \%$ higher status & 0.779 & 0.899 \\
\hline No. job opps. with $+/-10 \%$ status & 0.549 & 0.545 \\
\hline No. job opps. with more than $10 \%$ lower status & 1.869 & 0.600 \\
\hline No. job opps. in current (last) occupation & 1.079 & 1.193 \\
\hline \multicolumn{3}{|l|}{ Job context } \\
\hline Self-employed & 0.762 & 0.426 \\
\hline Firm type: private & 0.281 & 0.450 \\
\hline Firm size $>100$ employees & 0.063 & 0.242 \\
\hline Formal authority & 0.299 & 0.458 \\
\hline Values missing & 0.024 & 0.152 \\
\hline Occupational group (office / administrative clerks) & 0.225 & 0.418 \\
\hline Agricultural Occupations & 0.047 & 0.211 \\
\hline Textile occupations & 0.006 & 0.078 \\
\hline Wood and paper occupations & 0.019 & 0.135 \\
\hline Higher service sector occupations & 0.004 & 0.061 \\
\hline Restaurant / housekeeping occupations & 0.065 & 0.247 \\
\hline Cleaning/personal hygiene occupations & 0.026 & 0.159 \\
\hline Teaching, social, counseling occupations & 0.069 & 0.253 \\
\hline Other occupations & 0.540 & 0.498 \\
\hline \multicolumn{3}{|l|}{ Human capital and control variables } \\
\hline Education (Vocational training) & 0.568 & 0.495 \\
\hline Compulsory education & 0.203 & 0.402 \\
\hline Higher Education & 0.229 & 0.420 \\
\hline Training spell after labor market entry & 0.078 & 0.269 \\
\hline Labor market experience & 52.826 & 54.251 \\
\hline Spell out of labor force & 0.193 & 0.394 \\
\hline Sex: women & 0.504 & 0.500 \\
\hline Birth cohort: 1959-61 & 0.410 & 0.492 \\
\hline
\end{tabular}

\footnotetext{
a Based on episode files with $\mathrm{N}=22227$ (upward mobility) / 22705 (lateral mobility) / 22705 (downward mobility)
} 